\title{
PENINGKATAN PEMAHAMAN KONSEP MATEMATIKA SISWA KELAS $X$ MIPA 2 SMA NEGERI 1 KEDIRI MELALUI PENERAPAN MODEL PEMBELAJARAN REALISTIK DENGAN SETTING KOOPERATIF BERBANTUAN LKS TERSTRUKTUR
}

\author{
N.W.A. Prastyani, I.P.W.Ariawan, I. G. P. Suharta \\ Jurusan Matematika Universitas Pendidikan Ganesha \\ Singaraja, Indonesia \\ e-mail: andhikaprastyani@yahoo.com, wisnab36@gmail.com \\ , igpsuharta@yahoo.com
}

\begin{abstract}
Abstrak
Penelitian ini bertujuan untuk mengetahui: (1) peningkatan pemahaman konsep matematika siswa melalui penerapan model pembelajaran RESIK(Realistik Dengan Setting Kooperatif) Berbantuan LKS Terstruktur dan (2) tanggapan siswa terhadap penerapan model pembelajaran RESIK Berbantuan LKS Terstruktur. Jenis penelitian ini adalah penelitian tindakan kelas yang dilaksanakan dalam tiga siklus. Subjek penelitian ini adalah siswa kelas X MIPA 2 SMA Negeri 1 Kediri sebanyak 36 orang siswa pada semester ganjil Tahun Ajaran 2018/2019. Pengumpulan data pemahaman konsep matematika siswa pada penelitian ini menggunakan tes uraian, dan tanggapan siswa dikumpulkan menggunakan angket. Data yang telah terkumpul selanjutnya dianalisis secara deskriptif. Hasil penelitian menunjukkan bahwa peningkatan optimal terjadi pada siklus III dengan rata-rata skor 77,93 dan ketuntasan belajar $83,33 \%$. Peningkatan yang optimal pada siklus III terjadi karena, (1) guru melakukan kegiatan tanya jawab sehingga siswa dapat memberikan alasan atas jawaban yang disampaikan, (2) guru memberikan penjelasan kembali terkait konsep yang belum dipahami oleh siswa, (3) memberikan pertanyaan-pertanyaan pancingan kepada siswa dan memberikan tugas mandiri untuk dikerjakan di rumah agar siswa lebih mudah memahami konsep matematika.(4) Pembelajaran menggunakan masalah kontekstual yang diangkat pada awal pembelajaran. Selain itu tanggapan siswa terhadap penerapan model pembelajaran RESIK Berbantuan LKS Terstruktur ditinjau dari rata-rata skor tanggapan siswa sebesar 52,55 berada dalam kategori sangat positif.
\end{abstract}

Kata Kunci : pemahaman konsep matematika, model pembelajaran RESIK berbantuan LKS Terstruktur, tanggapan siswa

\begin{abstract}
This study is conducted to determine: (1) the improvement of students' comprehension of math concepts through the implementation of RESIK (Realistic With Cooperative Setting) learning model assisted by Structured LKS and (2) students' responses toward the implementation of RESIK learning model assisted by Structured LKS. This kind of study is a classroom activity research that conducted in three cycles. The subjects were 36 students of $X$ Mathematics 2 class at SMA Negeri 1 Kediri in the first semester of 2018/2019. The data collection of this study using an essay test, and student responses were collected using a questionnaire. The collected data is analyzed descriptively. The result shows that the significant enhancement arises in third cycle with an average score of 77,93 and $83.33 \%$ completeness of learning. This significant enhancement is arose by several things, (1) teacher conducting a question and answer activity that encourages students to give reasonable argument toward their answer, (2) the teacher retells related concepts that have not been understood by the students, (3) the teacher provides stimulus questions and give individual homework to make the students understand the mathematical concepts better.(4) Learning uses contextual problems that are raised at the beginning of learning In addition, the average score of students' responses toward the implementation of RESIK assisted by Structured LKS is 52.55 which belong to positive category.
\end{abstract}

Keywords: Comprehension of mathematical concepts, RESIK learning model assisted by Structured LKS, students' responses 


\section{PENDAHULUAN}

Matematika merupakan ilmu dasar yang memiliki peran yang sangat penting dan dipelajari oleh semua jenjang pendidikan. Mengingat pentingnya matematika membuat pelajaran matematika wajib diajarkan pada jenjang pendidikan Sekolah Dasar (SD), Sekolah Menengah Pertama (SMP), dan Sekolah Menengah Atas (SMA). Adapun tujuan pembelajaran matematika di sekolah diantaranya: (1) Memahami konsep matematika, menjelaskan keterkaitan antarkonsep dan mengaplikasikan konsep atau algoritma, secara luwes, akurat, efisien, dan tepat, dalam pemecahan masalah, (2) Menggunakan penalaran pada pola dan sifat, melakukan manipulasi matematika dalam membuat generalisasi, menyusun bukti, atau menjelaskan gagasan dan pernyataan matematika, (3) Memecahkan masalah yang meliputi kemampuan memahami masalah, merancang model matematika, menyelesaikan model dan menafsirkan solusi yang diperoleh, (4) Mengkomunikasikan gagasan dengan simbol, tabel, diagram atau media lain untuk memperjelas keadaan atau masalah, (5) Memiliki sikap menghargai kegunaan matematika dalam kehidupan, yaitu memiliki rasa ingin tahu, perhatian, dan minat dalam mempelajari matematika, serta sikap ulet dan percaya diri dalam pemecahan masalah (Permendiknas, 2006).

Dilihat dari tujuan pembelajaran matematika di atas, pemahaman konsep merupakan hal yang sangat penting dalam belajar matematika. Pelajaran matematika merupakan pelajaran yang terdiri dari beberapa konsep yang tersusun secara hirarki, yang berarti bahwa pemahaman konsep sebelumnya akan berpengaruh terhadap pemahaman konsep berikutnya. Apabila di awal terjadi kesalahan pemahaman konsep maka akan berpengaruh terhadap pemahaman konsep berikutnya. Kemampuan pemahaman konsep menjadi sesuatu yang harus dimiliki oleh siswa, karena dengan memahami konsep siswa lebih mudah dalam memecahkan permasalahan yang diberikan.

Siswa yang memiliki pemahaman konsep yang baik dapat dilihat dari indikator kemampuan pemahaman konsep matematika yang terdapat dalam National Council of Teacher of Mathematics (2000:11) yaitu (1) Describe concept in their own words (menyatakan konsep dalam kata - kata sendiri), (2) Identify or give examples and nonexamples of concept ( mengidentifikasi atau memberi contoh atau bukan contoh dari konsep),(3) Use concept correctly in a variety of situations (mengaplikasikan atau menggunakan konsep dengan benar dalam berbagai situasi). Pada kenyataannya matematika yang begitu besar manfaatnya dalam kehidupan pada umumnya tidak diimbangi dengan kemampuan pemahaman konsep siswa sehingga siswa tidak dapat memahami apa yang mereka pelajari. Hal ini terbukti dari sebagian besar siswa masih menganggap matematika dianggap sebagai pelajaran yang sulit dan tidak menyenangkan, sehingga ketika akan mengikuti pembelajaran matematika banyak siswa yang kurang antusias dalam mengikuti pembelajaran matematika.

Sekolah yang mengalami hal sama terjadi pada pembelajaran Matematika adalah SMA Negeri 1 Kediri khususnya di kelas X MIPA 2 tahun pelajaran 2018/2019 Berdasarkan observasi yang peneliti lakukan di Kelas X MIPA 2 SMA Negeri 1 Kediri pada bulan juli 2018 ditemui permasalahan dalam proses belajar matematika yaitu siswa kurang aktif dalam mengikuti pembelajaran dimana keaktifan didominasi oleh beberapa siswa saja, siswa cenderung belajar secara individu sehingga siswa enggan untuk belajar berkelompok, dan siswa masih malu bertanya pada guru jika mengalami kesulitan dalam memahami atau menyelesaikan soal yang diberikan.

Berdasarkan hasil observasi, wawancara dan tes awal pemahaman konsep yang diberikan dapat disimpulkan bahwa permasalahan yang terdapat di kelas $X$ MIPA 2 SMA Negeri 2 Kediri adalah rendahnya pemahaman konsep matematika yang dimiliki siswa. Hal ini di sebabkan karena beberapa faktor yaitu Pertama, dalam pembelajaran terbatasnya kesempatan siswa untuk menyampaikan kembali konsep- konsep yang telah diajarkan oleh guru dengan pemahaman siswa sendiri, Kedua, dalam pembelajaran 
tidak ada kesempatan bagi siswa untuk memberikan contoh dan bukan contoh yang akan berakibat pada siswa yang memiliki pemahaman yang yang salah ataupun kurangnya pemahaman siswa terkait materi yang telah diajarkan, Ketiga, tidak ada kesempatan bagi siswa untuk mengidentifikasi kembali jawaban, Keempat, dalam proses pembelajaran jika siswa di arahkan untuk belajar berkelompok siswa tersebut biasanya tidak mau belajar dengan kelompoknya

Untuk mengatasi permasalahan tersebut adalah dengan melakukan suatu alternatif model pembelajaran yang tepat sehingga dapat meningkatkan kemampuan pemahaman konsep siswa. Salah satu model pembelajaran yang dapat digunakan untuk meningkatkan pemahaman konsep matematika siswa adalah model pembelajaran Realistik dengan Setting kooperatif (RESIK)

Menurut (Suradi, 2008:14), "Model Pembelajaran Realistik dengan setting kooperatif (RESIK) merupakan pembelajaran realistik yang pelaksanaannya disetting secara kooperatif atau pembelajaran berkelompok dimana dalam pembelajarannya lebih banyak berpusat pada siswa". Salah satu ciri dari pembelajaran matematika dengan menggunakan model RESIK adalah dengan menggunakan masalah kontekstual yang diangkat sebagai masalah awal dalam pembelajaran (Suradi, 2008). Suradi (2008) mengungkapkan ada 6 fase dalam model pembelajaran RESIK, yaitu 1) memotivasi siswa, 2) menyajikan informasi dan melibatkan siswa memahami masalah kontekstual, 3) mengorganisasi siswa ke dalam kelompok belajar dan memberikan tugas kelompok, 4) membimbing kelompok bekerja dan belajar, 5) diskusi dan negosiasi, 6) evaluasi dan penghargaan.

Untuk mengoptimalkan proses belajar model pembelajaran RESIK maka dapat dibantu dengan LKS TerstrukturLKS terstruktur adalah lembar kerja yang dirancang untuk membimbing siswa dalam suatu pelajaran dengan sedikit atau sama sekali tanpa bimbingan guru untuk mencapai sasaran yang dituju dalam pembelajaran tersebut. LKS terstruktur membantu guru dalam menerapkan metode diskusi dengan baik. LKS terstruktur dilengkapi dengan petunjuk dan pengarahan tetapi tidak dapat menggantikan peranan guru dalam proses pembelajaran. Dimana dalam LKS ini ringkasan materi ajar disusun secara sistematis, kemudian diikuti dengan penyajian contoh soal dan soal - soal mulai dari yang mudah sampai soal yang sukar. Melalui berfikir lebih terstruktur atau sistematis. Dengan demikian, model pembelajaran RESIK dibantu dengan LKS Terstruktur akan memberikan kesempatan kepada siswa untuk meningkatkan kemampuan pemahaman konsep siswa

Adapun tujuan dari penelitian ini adalah (1) Untuk mengetahui peningkatan pemahaman konsep matematika siswa Kelas X MIPA 2 SMA Negeri 1 Kediri melalui penerapan model pembelajaran RESIK berbantuan LKS Terstruktur. (2) Untuk mengetahui tanggapan siswa Kelas X MIPA 2 SMA Negeri 1 Kediri terhadap penerapan model pembelajaran RESIK berbantuan LKS Terstruktur.

\section{METODE}

Penelitian yang akan dilaksanakan adalah penelitian tindakan kelas (classroom action research) yang secara umum bertujuan meningkatkan dan memperbaiki kualitas, proses, dan hasil pembelajaran matematika di kelas. Penelitian ini dilaksanakan dalam 3 (tiga) siklus. Dalam penelitian ini, PTK yang digunakan adalah model Kurt Lewin. Menurut Kurt Lewin (dalam Sanjaya, 2009) setiap siklus terdiri atas 4 (empat) tahap yaitu perencanaan tindakan, pelaksanaan tindakan, observasi dan evaluasi serta refleksi. Data pemahaman konsep matematika dikumpulkan menggunakan tes uraian yang diberikan pada setiap akhir siklus. Adapun rubrik penskoran pemahaman konsep matematika siswa adalah sebagai berikut.

Tabel 1. Rubrik Penskoran Pemahaman Konsep Matematika 


\begin{tabular}{|c|c|c|c|}
\hline \multicolumn{2}{|c|}{ Indikator } & Kriteria Jawaban & Skor \\
\hline & \multirow{3}{*}{$\begin{array}{l}\text { Menyatakan ulang } \\
\text { konsep dengan kata- } \\
\text { kata sendiri }\end{array}$} & $\begin{array}{l}\text { Menyatakan ulang suatu konsep dengan kata- } \\
\text { kata sendiri dengan benar }\end{array}$ & 2 \\
\hline & & $\begin{array}{l}\text { Menyatakan ulang suatu konsep dengan kata- } \\
\text { kata sendiri tetapi tidak sepenuhnya benar. }\end{array}$ & 1 \\
\hline & & $\begin{array}{l}\text { Salah dalam menyatakan ulang suatu konsep } \\
\text { dengan kata- kata sendiri }\end{array}$ & 0 \\
\hline \multirow[t]{3}{*}{2.} & \multirow{3}{*}{$\begin{array}{l}\text { Mengidentifikasi } \\
\text { yang termasuk } \\
\text { contoh atau bukan } \\
\text { contoh dari konsep } \\
\text { yang diperoleh }\end{array}$} & $\begin{array}{l}\text { Mengidentifikasi yang termasuk contoh atau } \\
\text { bukan contoh dari konsep yang diperoleh dengan } \\
\text { benar }\end{array}$ & 2 \\
\hline & & $\begin{array}{l}\text { Mengidentifikasi yang termasuk contoh atau } \\
\text { bukan contoh dari konsep yang diperoleh tetapi } \\
\text { tidak sepenuhnya benar }\end{array}$ & 1 \\
\hline & & $\begin{array}{l}\text { Salah dalam mengidentifikasi yang termasuk } \\
\text { contoh atau bukan contoh dari konsep yang } \\
\text { diperoleh }\end{array}$ & 0 \\
\hline \multirow{5}{*}{\multicolumn{2}{|c|}{ 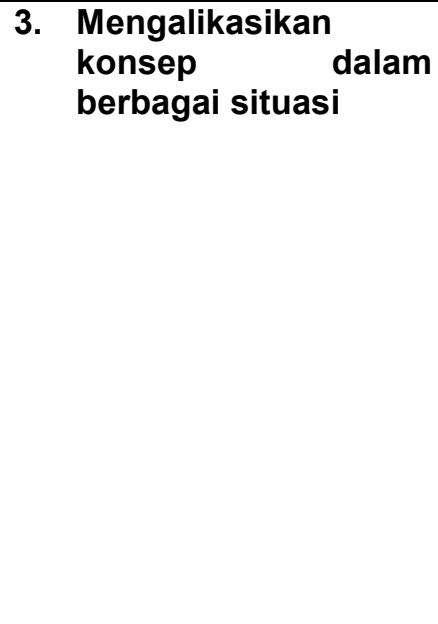 }} & $\begin{array}{l}\text { Mengaplikasikan konsep dalam berbagai situasi } \\
\text { dengan benar, perhitungan dan jawaban akhir } \\
\text { benar }\end{array}$ & 4 \\
\hline & & $\begin{array}{l}\text { Mengaplikasikan konsep dalam berbagai situasi } \\
\text { dengan benar, sebagian besar perhitungan benar } \\
\text { namun jawaban akhir salah }\end{array}$ & 3 \\
\hline & & $\begin{array}{l}\text { Mengaplikasikan konsep dalam berbagai situasi } \\
\text { dengan benar tetapi perhitungan dan jawaban } \\
\text { akhir salah. }\end{array}$ & 2 \\
\hline & & $\begin{array}{l}\text { Tidak benar mengaplikasikan konsep dalam } \\
\text { berbagai situasi }\end{array}$ & 1 \\
\hline & & $\begin{array}{l}\text { Tidak membuat jawaban atau hanya mengulang } \\
\text { informasi yang diketahui dari soal }\end{array}$ & 0 \\
\hline
\end{tabular}

(dimodifikasi dari NCTM, 2000)

Selain itu data tanggapan siswa terhadap penerapan model pembelajaran RESIK Berbantuan LKS Terstruktur dikumpulkan menggunakan angket tanggapan siswa diberikan pada saat akhir penelitian. Kriteria penilaian tanggapan menggunakan Skala Likert dengan masingmasing 5 pilihan yaitu Sangat Setuju (SS), Setuju (S), Kurang Setuju (KS), Tidak Setuju (TS), dan Sangat Tidak Setuju (STS)

\section{HASIL DAN PEMBAHASAN \\ HASIL}

\section{Hasil Penelitian Refleksi Awal}

Pada tahap refleksi awal, siswa kelas $X$ MIPA 2 SMA Negeri 1 Kediri diberikan tes awal pemahaman konsep matematika berbentuk soal uraian. Dari hasil analisis data pemahaman konsep matematika siswa sebelum pelaksanaan tindakan terlihat bahwa nilai terendah adalah 25 dan nilai tertinggi adalah 87,5 .

Persentase banyaknya siswa yang belum tuntas adalah $88,89 \%$ (32 orang), sedangkan persentase banyaknya siswa yang sudah tuntas adalah $11,12 \%$ (4 orang). Sebaran pemahaman konsep matematika siswa pada refleksi awal disajikan dalam Gambar 1.1 berikut. 


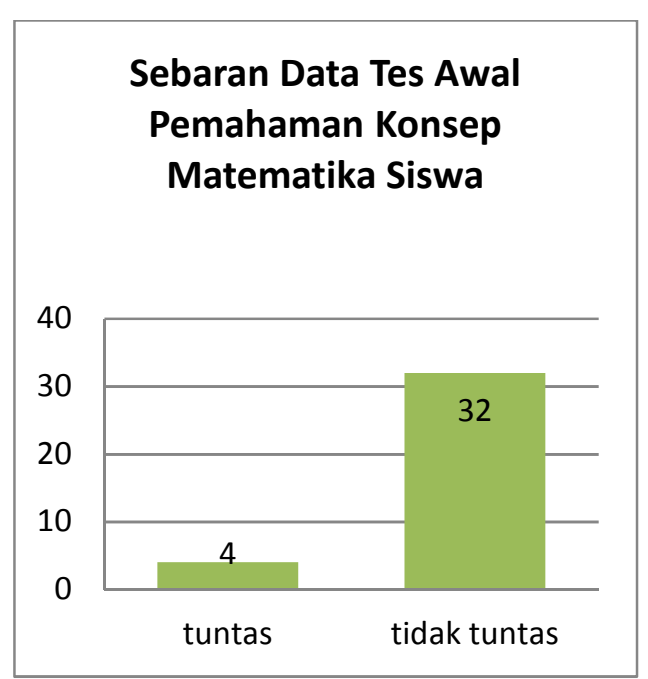

Gambar 1.1 Sebaran Data Tes Awal Pemahaman Konsep Matematika Siswa

Berdasarkan tes awal yang diberikan, jumlah total nilai pemahaman konsep matematika siswa adalah 1950 dengan banyak siswa adalah 36 orang, sehingga rata-rata nilai pemahaman konsep matematika siswa adalah 54,17. Jika dibandingkan dengan kriteria ketuntasan pemahaman konsep matematika siswa yang sudah ditetapkan sebelumnya maka ratarata nilai pemahaman konsep matematika siswa pada refleksi awal ini tergolong belum tuntas.

\section{Hasil Penelitian Siklus I}

Pada akhir siklus I siswa diberikan tes pemahaman konsep matematika yang terdiri dari lima butir soal uraian. Dari analisis data tersebut diperoleh rata-rata nilai pemahaman konsep matematika siswa adalah 56,25 dan ketuntasan belajar secara klasikal $30,56 \%$ yaitu hanya 11 siswa dari 36 siswa yang mampu mencapai KKM. Adapun sebaran data pemahaman konsep matematika siswa dapat diperhatikan pada gambar 1.2 berikut.
Grafik Sebaran Tes Kemampuan

Pemahaman Konsep matematika pada Siklus I

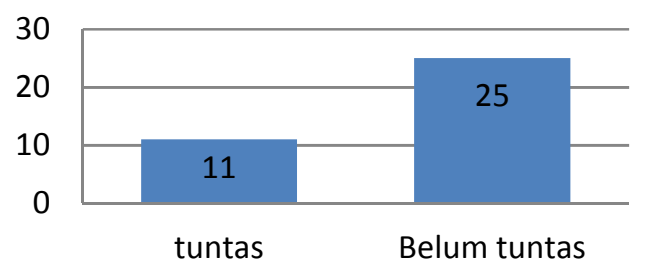

Gambar 1.2 Sebaran Data Pemahaman Konsep Matematika Siswa Siklus I

Dapat disimpulkan bahwa rata-rata nilai pemahaman konsep matematika siswa pada siklus I belum memenuhi kriteria indikator keberhasilan yang telah ditetapkan, karena rata-ratanya berada di bawah 70 yaitu 56,25. Selain itu, ketuntasan belajar siswa secara klasikal juga kurang dari $70 \%$ yaitu $30,55 \%$ sehingga masih berada dalam kategori belum tuntas.

\section{Hasil Penelitian Siklus II}

Pada akhir siklus II siswa diberikan tes pemahaman konsep matematika yang terdiri dari empat butir soal uraian. Dari analisis data tersebut diperoleh rata-rata nilai pemahaman konsep matematika siswa adalah 68,79 dan ketuntasan belajar secara klasikal 55,55\%. Dengan demikian, persentase banyaknya siswa yang tuntas adalah 55,55\% (20 orang), sedangkan persentase banyaknya siswa yang tidak tuntas adalah 44,44\% (16 orang). Sebaran data skor pemahaman konsep matematika siswa siklus II disajikan pada gambar 1.3 berikut. 


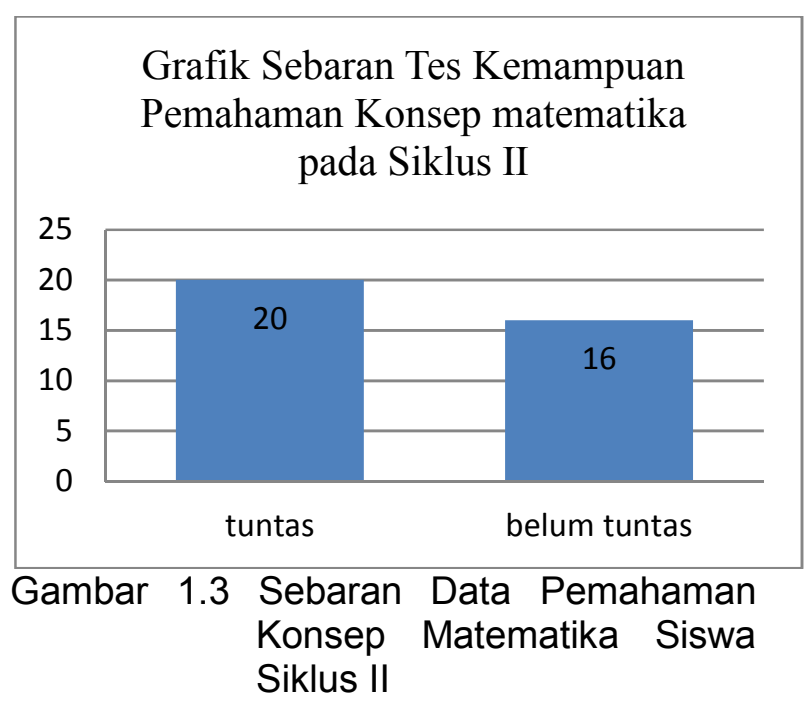

Berdasarkan analisis data di atas, dapat disimpulkan bahwa rata-rata skor pemahaman konsep matematika siswa pada siklus II belum memenuhi kriteria indikator keberhasilan yang telah ditetapkan, karena rata-ratanya berada di bawah 70 yaitu 68,79. Selain itu, ketuntasan belajar siswa secara klasikal juga kurang dari $70 \%$ yaitu $55,55 \%$ sehingga masih berada dalam kategori belum tuntas. Walaupun demikian, rata-rata nilai pemahaman konsep matematika siswa, dan ketuntasan belajar siswa sudah mengalami peningkatan dari siklus I ke siklus II.

\section{Hasil Penelitian Siklus III}

Pada akhir siklus III siswa diberikan tes pemahaman konsep matematika yang terdiri dari tiga butir soal uraian. Dari analisis data tersebut diperoleh rata-rata nilai pemahaman konsep matematika siswa pada siklus III adalah 77,79 dan ketuntasan belajar secara klasikal 83,33\%. Dengan demikian, persentase banyaknya siswa yang tuntas adalah 83,33\% (30 orang), sedangkan persentase banyaknya siswa yang tidak tuntas adalah $16,66 \%$ (6 orang). Sebaran data skor pemahaman konsep matematika siswa siklus III disajikan pada gambar 1.4 berikut.

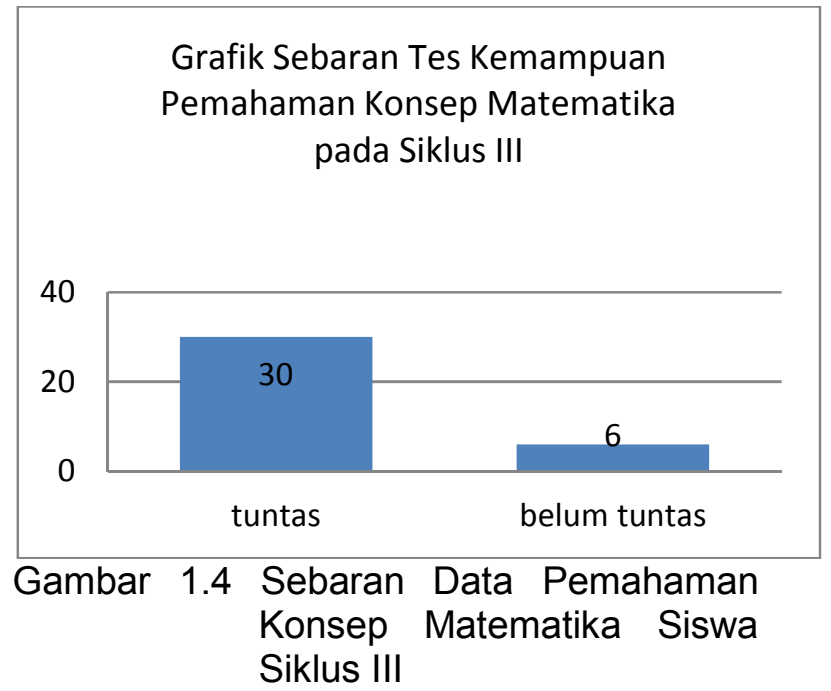

Berdasarkan analisis data di atas, dapat disimpulkan bahwa rata-rata skor pemahaman konsep matematika siswa pada siklus III sudah memenuhi kriteria indikator keberhasilan yang telah ditetapkan dan mengalami peningkatan dari siklus II. Hal tersebut dapat dilihat dari rata-rata skor pemahaman konsep matematika siswa berada di atas 70 yaitu 77,79 dan ketuntasan belajar siswa secara klasikal lebih dari $70 \%$ yaitu $83,33 \%$.

\section{Peningkatan Pemahaman Konsep Matematika Siswa}

Peningkatan

rata-rata nilai pemahaman konsep matematika siswa ditunjukkan dengan grafik seperti Gambar 1.5 berikut ini.

\section{Grafik Peningkatan Rata-Rata Nilai Pemahaman Konsep Matematika}

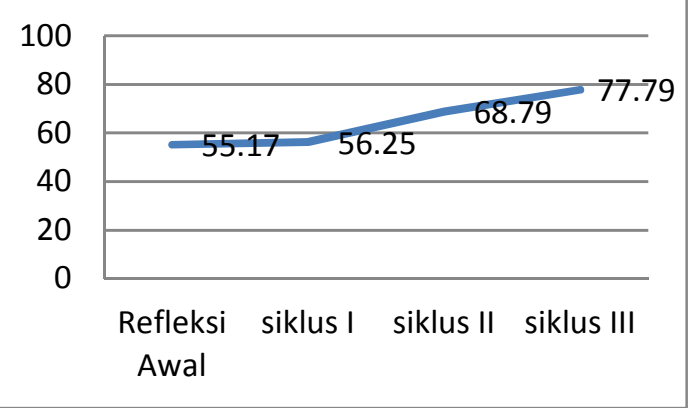


Gambar 1.5 Grafik Peningkatan Rata-Rata Nilai Komunikasi Matematis Siswa

Peningkatan rata-rata skor pemahaman konsep matematika siswa dari refekesi awal ke siklus 1 adalah 1,08, siklus I ke siklus II adalah 12,54. Sedangkan peningkatan dari siklus II ke siklus III adalah 9,14 . Sehingga untuk peningkatan pemahaman konsep matematika dari refleksi awal ke siklus III adalah 22,62 .

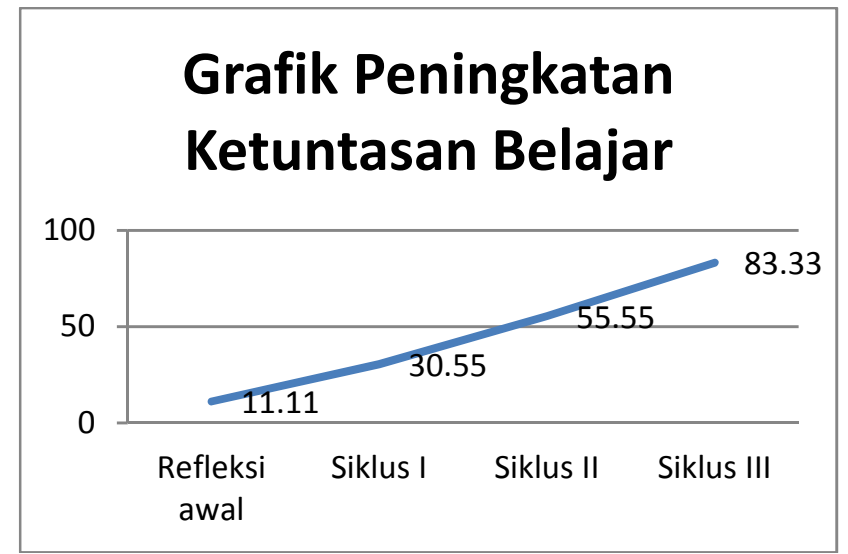

Gambar 1.6 Grafik Peningkatan Ketuntasan Belajar Siswa .

\section{Tanggapan Siswa}

Pada akhir pertemuan siklus III, siswa juga diberikan angket untuk mengetahui tanggapan siswa terhadap penerapan model pembelajaran RESIK berbantuan LKS Terstruktur. Data mengenai tanggapan siswa terhadap penerapan model pembelajaran RESIK berbantuan LKS Terstruktur dikumpulkan pada akhir siklus III dengan menggunakan angket tanggapan siswa yang terdiri dari 15 butir pernyataan. Berdasarkan data tersebut diperoleh ratarata skor tanggapan siswa terhadap penerapan model pembelajaran RESIK Berbantuan LKS Terstruktur selama proses pembelajaran adalah 52,67.

Sebaran data tanggapan siswa disajikan pada Gambar 1.8 berikut.

\section{Persentase tanggapan siswa}

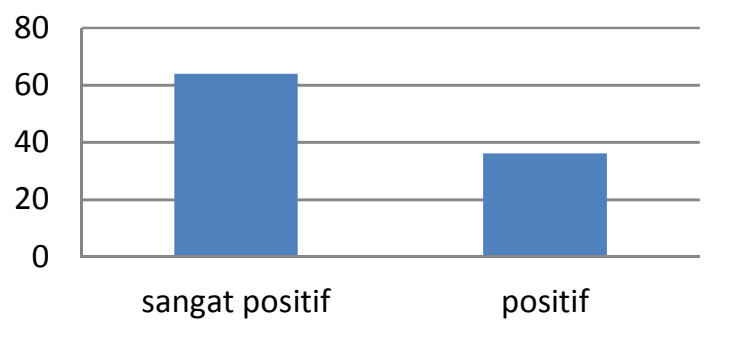

Gambar 1.7 Persentase Tanggapan Siswa

Berdasarkan rata-rata skor tanggapan siswa $(\bar{T}=52,67)$, dapat disimpukan bahwa pembelajaran melalui model pembelajaran RESIK Berbantuan LKS Terstruktur mendapatkan tanggapan yang sangat positif dari siswa sesuai dengan kriteria penggolongan tanggapan siswa sehingga tanggapan siswa terhadap penerapan model pembelajaran RESIK Berbantuan LKS Terstruktur sudah memenuhi kriteria indikator keberhasilan.

\section{PEMBAHASAN}

Tercapainya

peningkatan pemahaman konsep matematika yang dimiliki siswa secara optimal terjadi pada siklus III, hal ini dapat dilihat dengan adanya peningkatan hasil tindakan yang dilakukan untuk menyelesaikan permasalahan yang ditemui pada observasi dan setalah adanya pelaksanaan tindakan pada siklus I hingga siklus III sudah mengalami perubahan dan peningkatan dari siklus ke siklus. Adapun hal - hal yang menyebabkan terjadinya peningkatan pemahaman konsep matematika yang dimiliki oleh siswa sebagai berikut :

Pertama, proses pembelajaran lebih menekankan pada penggalian kembali konsep relevan yaitu dengan mengarahkan siswa melalui pertanyaan - pertanyaan pancingan yang dapat merangsang siswa untuk mengkontruksi pengetahuannya sendiri. Tindakan ini dapat mengurangi siswa yang masih kesulitan memahami, mengkontruksi, mengidentifikasi, dan menyelesaikan permasalahan yang berada pada LKS. Pada tahap ini siswa menganggap konsep baru yang akan di pelajari sebagai perumusan yang mirip dengan konsep yang sudah dikuasai. Hal ini 
menyebabkan siswa memiliki konsep yang kuat karena siswa dapat melihat kemiripan konsep yang sudah dikuasai dengan konsep baru dan mampu menyampaikan konsep baru yang dimiliki dengan bahasanya sendiri sesuai dengan pengetahuan atau konsep awal yang dimiliki siswa. Dengan begitu, siswa sudah paham dasar dan mempelajari konsep baru adalah konsep - konsep yang sudah di pelajari sebelumnya. Hal ini sesuai dengan pendapat Ardana(2012) yaitu siswa belajar matematika dengan memahami melalui ikut serta aktif membangun pengetahuan baru berdasarkan pengalaman dan pengetahuan sebelumnya. Artinya untuk menguasai konsep matematika dengan baik, siswa harus memahami dan menganggap matematika itu bukanlah barang jadi yang siap diterima begitu saja oleh siswa, tetapi matematika harus dikontruksi siswa.

Kedua memperkuat pemahaman konsep siswa dengan secara kontinu memberikan permasalahan - permasalahan melalui pemberian tugas mandiri. Dengan penegerjaaan berbagai permasalahan, siswa terbiasa menggunakan dan mengembangkan pemahaman konsepnya dalam menyelesaikan masalah. Secara tidak langsung ini akan memperkuat pemahaman konsep siswa terhadap suatu materi. Siswa akan lebih paham tentang kedalaman suatu konsep ketika siswa menggunakannya dalam menyelesaikan masalah. Hal ini sesuai dengan pendapat yang dikemukakan oleh Crawford(2001:12) yang menyatakan metode pembelajaran yang dilaksanakan berfokus pada kebermaknaan aspek aktivitas pembelajaran artinya guru harus menekankan pemberian tugas di dalam kelas sebagai sesuatu yang relevan dan autentik yang memiliki makna dalam dunia nyata.

Ketiga, memberikan kesempatan dan penekanan kepada siswa untuk aktif memberikan tanggapan, menyampaikan hasil diskusi, menjawab ataupun memberikan sanggahan mengenai konsep konsep yang dipelajari dengan memberikan bimbingan dan motivasi. Melalui tahap ini siswa dapat menyamakan persepsi guru memgetahui keunikan atau ciri khas suatu konsep dengan menyampaikan hasil diskusi kelompok dalam mengerjakan LKS, siswa dapat memberikan tanggapan, pertanyaan, menjawab ataupun sanggahan disertai alas an. Untuk menghindari kendala yang ditemukan pada siklus I dan II terkait dengan keseriusan siswa dalam mengikuti pembelajaran masih kurang dan terdapatnya beberapa kelompok yang didominasi satu orang saja maka guru juga mendekati siswa yang tidak mau berpatisipasi dalam diskusi kelompok dan mengarahkan siswa yang bersangkutan agar berusaha mengerjakan persoalan dengan ikut berpatifipasi aktif dalam diskusi kelompok.Tindakan ini sangat efisien dilakukan karena jika dilihat dari pelaksanaan siklus I hingga siklus III terdapat perubahan dan perkembangan dalam kemampuan memberikan tanggapan menyampaikan hasil diskusi, menjawab ataupun memberikan sanggahan mengenai konsep - konsep yang di pelajari yang dialami siswa. Dengan penguasaan konsep yang mantap dapat mempererat jalinan konsep - konsep yang dipelajari akan menyebabkan suatu konsep tersebut melekat dalam struktur kognitif siswa. Hal ini sesuai dengan apa yang disampaikan oleh Depdiknas (2016) menyatakan bahwa siswa akan mempelajari matematika jika mereka mempunyai motivasi, yang dalam proses pembelajaran dapat dilaksanakan oleh individu maupun kelompok.

Melalui perbaikan - perbaikan yang dilakukan oleh guru dalam proses pembelajaran dari siklus I, siklus II dan siklus III membuat siswa lebih memahami konsep matematika seperti membimbing secara intensif, motivasi dan penguatan kepada siswa dengan begitu siswa lebih paham dan mengerti manfaat mempelajari materi yang telah diberikan. Sehingga pada siklus III tidak terdapat lagi permasalahan yang berarti. Hal ini disebabkan karena proses pembelajaran pada siklus III yang sudah semakin baik dan sesuai dengan harapan yang direncanakan dibandingkan dengan siklus siklus sebelumnya. Penerapan model pembelajaran RESIK berbantuan LKS Terstruktur berjalan dengan lancer, sudah sesuai dengan teori karena kendala kendala yang dihadapi mampu diselesaikan melalui refleksi setiap proses pembelajaran maupun setiap siklusnya sehingga 
pemahaman konsep matematika yang dimiliki siswa dalam pembelajaran yang dilakukan telah mengalami peningkatan dari siklus ke siklus

Selain terjadi peningkatan pemahaman konsep matematika siswa, penerapan model pembelajaran RESIK berbantuan LKS Terstruktur juga mendapatkan respon yang sangat positif dari siswa. Rata-rata skor tanggapan siswa diperoleh sebesar 52,67. Berdasarkan kriteria penggolongan tanggapan siswa maka tanggapan siswa berada pada kategori sangat positif. Dengan demikian, hasil penelitian ini telah memenuhi semua indikator keberhasilan yang telah ditetapkan. Jadi dapat disimpulkan penelitian sudah berhasil.

\section{SIMPULAN DAN SARAN Simpulan}

Berdasarkan hasil analisis data dan pembahasan hasil penelitian, diperoleh simpulan sebagai berikut.

Peningkatan pemahaman konsep matematika siswa Kelas X MIPA 2 SMA Negeri 1 Kediri yang dapat dicapai melalui penerapan model pembelajaran RESIK berbantuan LKS Terstruktur dari Refleksi awal ke siklus I adalah sebesar 1,08 dengan rata rata refleksi awal yaitu 55,17 , siklus I ke siklus II sebesar 12,54 dengan rata-rata 56.25 pada siklus I menjadi 68,79 pada siklus II. Kemudian dari siklus II ke siklus III mengalami peningkatan sebesar 9,14 yaitu dari 68,79 menjadi 77,93 . Sehingga dapat dikatakan bahwa pemahaman konsep matematika siswa mengalami peningkatan optimal pada siklus III dengan rata-rata skor 77,93 , dengan ketuntasan belajar sebesar $83,33 \%$. Penerapan model pembelajaran RESIK berbantuan LKS Terstruktur mampu meningkatkan pemahaman konsep matematika siswa Kelas X MIPA 2 SMA Negeri 1 Kediri. Hal ini dapat dilihat dari peningkatan rata-rata skor pemahaman konsep matematika siswa dan proses peningkatan pemahaman konsep matematika siswa mengalami peningkatan dari siklus ke siklus. Peningkatan ini terjadi karena berbagai tindakan yang telah dilakukan oleh guru yaitu: 1) Pada awal pembelajaran guru memberikan apersepsi kepada siswa sehingga siswa tertarik untuk mengikuti pembelajaran, 2) Menyajikan informasi dan melibatkan siswa memahami masalah kontekstual sehingga membuat siswa tertarik dalam menyelesaikannya karena permasalahan yang diberikan dirasa dekat dengan kehidupan siswa menjadikan suasana menyenangkan bagi siswa, 3) Mengorganisasi siswa ke dalam kelompok belajar sehingga siswa yang memiliki kemampuan lebih bisa membaginya ke siswa yang memiliki kemampuan rendah 4) Memberikan kesempatan kepada siswa untuk menyampaikan pendapat, 5) Guru melakukan kegiatan tanya jawab dengan siswa agar siswa terbiasa memberikan alasan atas jawaban yang disampaikan.6) Pembelajaran menggunakan masalah kontekstual yang diangkat pada awal pembelajaran, 7) Memberikan pertanyaanpertanyaan pancingan kepada siswa dan memberikan tugas mandiri untuk dikerjakan di rumah agar siswa lebih mudah dalam memahami konsep yang diberikan.

Tanggapan siswa kelas X MIPA 2 SMA Negeri 1 Kediri terhadap penerapan model pembelajaran RESIK berbantuan LKS Terstruktur dikumpulkan melalui angket ditinjau dari rata-rata nilai tanggapan siswa berada dalam kategori sangat positif yaitu sebesar 52,66 . Menurut siswa pembelajaran yang diterapkan dapat memudahkan siswa dalam memahami konsep serta mampu mengingat konsep lebih lama karena siswa dapat menyampaikan kembali konsep yang diperoleh dengan bahasanya sendiri pada saat kegiatan berbagi informasi.

\section{Saran}

Berdasarkan hasil penelitian yang diperoleh, adapun saran yang penuiis dapat sampaikan yaitu sebagai berikut.

Model pembelajaran RESIK berbantuan LKS Terstruktur dapat meningkatkan pemahaman konsep matematika siswa. Untuk itu, guru matematika pada umumnya disarankan untuk mencoba menerapkan model pembelajaran RESIK berbantuan LKS Terstruktur pada materi lainnya dan guru harus mampu memilih materi yang benar-benar bisa diterapkan dengan model pembelajaran RESIK berbantuan LKS Terstruktur sehingga memperoleh hasil yang optimal. 


\begin{abstract}
Bagi pembaca berminat untuk melaksanakan penelitian lebih lanjut mengenai penerapan model pembelajaran RESIK berbantuan LKS Terstruktur diharapkan agar memperhatikan kendalakendala yang dialami selama pelaksanaan penelitian sebagai bahan pertimbangan untuk perbaikan dan penyempurnaan pelaksanaan penelitian
\end{abstract}

\title{
DAFTAR PUSTAKA
}

Depdiknas.2006. Standar Isi Untuk Satuan Pendidikan Dasar dan Menengah. Jakarta: Badan Standar Nasional Pendidikan

NCTM. 2000. Principles and Standards for School Mathematics. Reston VA:NCTM.

Sanjaya, Wina. 2008. Perencanaan dan Desain Sistem Pembelajaran. Jakarta: Kencana Prenada Media Group.

Sanjaya, Wina. 2009. Penelitian Tindakan Kelas. Jakarta: Kencana Prenada Media Group.

Suradi.2008."Model Pembelajaran Resik sebagai Strategi Mengubah Paradigma Pembelajaran Matematika di SMP yang Teacher Oriented menjadi Student Oriented". 